\title{
CASES OF STIGMATIZATION AND DISCRIMINATION AGAINST HIV AND HCV PATIENTS BY MEDICAL PERSONNEL - COMPARATIVE SURVEYS
}

\author{
Maciej Rogala', Ewa Donesch-Jeżo² \\ 1 DEPARTMENT OF HEALTH POLICY AND MANAGEMENT, INSTITUTE OF PUBLIC HEALTH, FACULTY OF HEALTH SCIENCES, \\ JAGIELLONIAN UNIVERSITY, MEDICAL COLLEGE, KRAKOW, POLAND \\ ${ }^{2}$ FACULTY OF PSYCHOLOGY AND HUMANITIES, ANDRZEJ FRYCZ MODRZEWSKI KRAKOW UNIVERSITY, KRAKOW, POLAND
}

\section{Key words: \\ stigmatization, discrimination, doctor-patient relations, impediment to grant health services, refusal of health services}

\begin{abstract}
Introduction: Research results indicate that in Poland stigmatization and discrimination against HIV patients is occurring on the part of medical personnel. This phenomenon is characterized by a poorer treatment of patients due to infection, impediments to access to health services or refusing to provide medical care.

The aim: The aim of the work was to analyze attitudes and the communication process between the patient and medical staff both before receiving health services as well as during the process of providing these services in order to investigate the causes and nature of the phenomenon of stigmatization and discrimination against patients with HIV and HCV by representatives of various medical professions.

Material and methods: The study was conducted among patients with diagnosed HIV - the primary group and among patients with HCV - the control group. A total of 160 patients with HIV and HCV were investigated at the two outpatient clinics of the University Hospital in Krakow. The research used the author's questionnaires of a comparative nature.

Results: Doctors, dentists, dental technicians, nurses and midwives are among the group of medical workers, who stigmatize and discriminate against patients diagnosed with HIV, which is manifested by the impediments or refusal to grant health services after the patient has provided information about the virus. The refusal to grant services to patients was often accompanied by the inducing guilt in patients due to having infection. Some patients withdrew themselves from health services despite the occurrence of medical need due to earlier ill-treatment by medical personnel. Patients, among the reasons for refusal, pointed to the personnel's excuses for too long queues of patients, lack of appropriate qualifications or appropriate technical capabilities. Similar attitudes, though much less frequently and to a lesser extent, were noted in patients with HCV, constituting a control group in this study. This type of attitude, manifested by stigmatization and discrimination against patients, was not observed among paramedics, who are the group of medical professionals particularly often exposed to contact with potentially infectious material and therefore to an increased risk of infection.

Conclusions: The cases of stigmatization and discrimination against patients with diagnosed HIV and HCV by medical personnel occur solely due to the patients' infection with the virus. Cases of refusal are accompanied by anxiety and a sense of threat of infection, which may be related to the state of knowledge of the prevention of viral infections. Resignation of patients from medical care despite the need for health due to previous negative experiences in such situations, impediments in granting medical care or refusal to provide health services may have negative health consequences for these patients, and in the longer term, generate higher costs for the health care system due to the abandonment of earlier pro-health activities.
\end{abstract}

\section{INTRODUCTION}

Stigmatization and discrimination are concepts used primarily in social sciences, and in medical sciences they are used in relation to beliefs and attitudes of medical personnel towards patients with HIV and AIDS, which, in turn, affect the nature of the relationship between them as well as the course of health services provided. The concept of stigmatization is associated with a pejorative social identity - it consists in branding individuals and more often the whole social groups by assigning them negative attributes or labels. Social stigmatization leads to rejection by designating stigmatized people with negative features, which disqualify them in the eyes of other people. Researchers of the problem of stigmatization of people with HIV indicate that prejudices, humiliation, discrediting and discrimination against these people are manifestations of stigmatization. They divided the stigma into innate and acquired, and the latter applies to HIV carriers. In the scientific literature there is the concept of the stigma associated with health status (health related stigma). There are also the concepts of the felt stigma and experienced stigma, where the experienced stigma means discrimination [1-13].

The term discrimination means unequal treatment, differentiation in an unfair way. Discrimination is classified on the scale of social rejection ranging from segregation to persecution, and its echoes are 
generalization, one-sidedness, pejorative evaluation, isolation, avoidance and limitation of opportunities. Discrimination usually refers to behaviors directed against other people, and results from their group membership. Its effect may be a sense of social exclusion. One of the elements of the World Health Organization (WHO) strategy towards the problem of HIV and AIDS is zero tolerance for discrimination against people with HIV (zero discrimination in a world where people live with HIV) due to reports about their difficult access to healthcare in some parts of the world. The problem of social exclusion was also raised by the institutions of the European Union, drawing attention in official documents to the problem of social exclusion, one of the manifestations of which is the impediment of access to health services of good quality. On these grounds, the year 2010 was announced by the EU the Year for Combating Poverty and Social Exclusion [14-20].

The problem of stigmatization and discrimination against patients diagnosed with HIV is practically present from the first half of the 80 s of the twentieth century, when a new virus was first diagnosed in people - for the most part in those with homosexual orientation but also in those overusing medicines - resulting in, among others, pneumonia caused by Pneumocystis carinii, Kaposi's sarcoma and viral infections at that time of unknown origin [21-22].

The research carried out at the turn of 1983-1984 led to the identification of a retrovirus which influenced the pathogenesis of Acquired Immunodeficiency Syndrome, also called Acquired Immune Deficiency Syndrome, and in 1986 gave the basis for the name of HIV (Human Immunodeficiency Virus) [23-26].

It was these two groups - homosexuals and people addicted to intravenous agents - which were initially determined as carriers of the virus. At that time, a person infected with the HIV was called using the stigmatizing term " $4 \mathrm{H}$ Disease", which indicated, in this way, the origin of the disease in one of four groups of people: Haitians, homosexuals, hemophiliacs and heroin users. Cases of stigmatization and discrimination against people with HIV and AIDS began to spread wherever there were people infected with this virus, and also occurred in Poland. While today AIDS is not referred to as a disease of homosexuals and drug addicts, these groups of people are still determined as "high-risk groups" in many regions of the world, including the entire Old Continent, causing negative social perception of people with HIV or AIDS. The results of many studies showing how important problems for patients with HIV and AIDS are cases of their stigmatization and discrimination on the part of medical personnel, including doctors, which often makes it difficult to get or even prevents from receiving medical care. Much less frequent in the literature are studies of the phenomenon of discrimination and stigmatization against $\mathrm{HCV}$ patients on the part of medical personnel. Though less time has passed since the diagnosis of infection with HCV than the detection of HIV - the first diagnosis of HIV infection was at the beginning of the 1980s and HCV at the end of the 1980s - it is not accompanied by such a negative attitude as in the case of HIV. However, the frequent occurrence of chronic infection with HCV and reported cases of stigmatization and discrimination against these persons may indicate an existing problem affecting at least some of the patients with this infection [27-31].

\section{THE AIM}

The aim of the work was to analyze cases of stigmatization and discrimination against HIV and HCV patients by representatives of various medical professions. For the purpose of the study, the course of the communication process between the patient and the medical staff was analyzed, and the dysfunctional effects of relations between them were assessed.

\section{MATERIAL AND METHODS}

The inclusion criterion was the diagnosis with HIV/ AIDS and the age between 18 and 65 years. HIV patients were included in the primary group. The control group consisted of patients diagnosed with HCV. A total of

Table 1. Number of patients.

\begin{tabular}{|l|l|c|c|c|c|}
\hline \multirow{2}{*}{\begin{tabular}{c}
\multirow{2}{*}{$\begin{array}{c}\text { Characteristics } \\
\text { of the group }\end{array}$} \\
\cline { 3 - 6 }
\end{tabular}} & \multicolumn{2}{|c|}{ Group } \\
\cline { 2 - 6 } & Number & HIV & Number & HCV \\
\hline \multirow{2}{*}{$\begin{array}{l}\text { Gender } \\
\mathbf{p}=\mathbf{0 , 0 0 3}\end{array}$} & Male & 60 & 75,0 & 42 & 52,5 \\
\cline { 2 - 6 } & Female & 20 & 25,0 & 38 & 47,5 \\
\hline
\end{tabular}

$\mathrm{p}-$ level of significance 
Table 2. Cancellation of visits to the GP or specialist.

\begin{tabular}{|l|c|c|c|c|}
\hline \multirow{2}{*}{$\begin{array}{c}\text { Abandonment of going to the GP or specialist in the past despite } \\
\text { the onset or worsening of symptoms (related to or not related } \\
\text { to HCV/HIV) or the perceived deterioration of health } \\
\mathbf{p}<\mathbf{0 0 0 1}\end{array}$} & \multicolumn{4}{|c|}{ Group } \\
\cline { 2 - 5 } & Number & {$[\%]$} & Number & HCV \\
\hline Yes & 60 & 75,0 & 78 & 97,5 \\
\hline No & 20 & 25,0 & 2 & 2,5 \\
\hline Total & 80 & 100,0 & 80 & 100,0 \\
\hline
\end{tabular}

$\mathrm{p}-$ level of significance

Table 3. Cancellation of medical help due to previous experience.

\begin{tabular}{|l|c|c|c|c|}
\hline \multirow{2}{*}{$\begin{array}{c}\text { Has it happened that you resigned from visiting } \\
\text { a medical facility (office, clinic) or admission to hospi- } \\
\text { tal ward due to previous unpleasant experience } \\
\text { NS }\end{array}$} & \multicolumn{2}{|c|}{ HIV } & \multicolumn{2}{|c|}{ HCV } \\
\cline { 2 - 5 } & Number & {$[\%]$} & Number & {$[\%]$} \\
\hline In the same facility & 6 & 37,5 & 1 & 50,0 \\
\hline In another facility & 10 & 62,5 & 1 & 50,0 \\
\hline Total & 16 & 100,0 & 2 & 100,0 \\
\hline
\end{tabular}

NS - lack of statistical significance

Table 4. Reasons for resigning from the clinic.

\begin{tabular}{|c|c|c|c|c|}
\hline \multirow{3}{*}{ Reasons for resignation } & \multicolumn{4}{|c|}{ Group } \\
\hline & \multicolumn{2}{|c|}{ HIV } & \multicolumn{2}{|c|}{ HCV } \\
\hline & Number & {$[\%]$} & Number & [\%] \\
\hline $\begin{array}{l}\text { Resignation from visiting the clinic because the clinic's working hours conflicted with family responsibilities } \\
\text { NS }\end{array}$ & 2 & 2,5 & 1 & 1,3 \\
\hline $\begin{array}{l}\text { Resignation from visiting the clinic because the clinic's working hours conflicted with professional responsibilities } \\
\text { NS }\end{array}$ & 5 & 6,3 & 0 & 0 \\
\hline $\begin{array}{l}\text { Resignation from visiting the clinic due to setting a distant date for a medical appointment } \\
p=0,034\end{array}$ & 8 & 10,0 & 1 & 1,3 \\
\hline $\begin{array}{l}\text { Resignation from visiting the clinic for fear of the doctor's reaction to news of the infection } \\
p=0,003\end{array}$ & 11 & 13,8 & 1 & 1,3 \\
\hline $\begin{array}{l}\text { Resignation from visiting the clinic for fear of another healthcare professional's reaction to news of the infection } \\
p=0,003\end{array}$ & 11 & 13,8 & 1 & 1,3 \\
\hline $\begin{array}{l}\text { Resignation from visiting the doctor because of past mistreatment by medical staff in a private doctor's office } \\
p=0,016\end{array}$ & 10 & 12,5 & 2 & 2,5 \\
\hline $\begin{array}{l}\text { Resignation from visiting the clinic because of poor treatment in the past by medical staff in the clinic/office } \\
\text { due to HCV/HIV infection } \\
p=0,009\end{array}$ & 11 & 13,9 & 2 & 2,5 \\
\hline $\begin{array}{l}\text { Resignation from visiting the clinic because of mistreatment in the past by medical staff in a hospital ward } \\
\text { due to HCV/HIV infection } \\
p=0,028\end{array}$ & 6 & 7,5 & 0 & 0,0 \\
\hline $\begin{array}{l}\text { Resignation from visiting the clinic because of prior arousing guilt by medical staff for being infected } \\
\text { with } \mathrm{HCV} / \mathrm{HIV} \\
\mathrm{p}=0,034\end{array}$ & 8 & 10,0 & 1 & 1,3 \\
\hline $\begin{array}{l}\text { Resignation from visiting the clinic for another reason } \\
\text { NS }\end{array}$ & 3 & 3,8 & 1 & 1,3 \\
\hline
\end{tabular}

$\mathrm{p}$ - level of significance, NS - lack of statistical significance 
Table 5. Refusal by the doctor to provide treatment after the patient's information about the virus.

\begin{tabular}{|c|c|c|c|c|}
\hline \multirow{3}{*}{ A doctor refusing to provide medical service } & \multicolumn{4}{|c|}{ Group } \\
\hline & \multicolumn{2}{|c|}{ HIV } & \multicolumn{2}{|c|}{ HCV } \\
\hline & Number & {$[\%]$} & Number & [\%] \\
\hline $\begin{array}{l}\text { Gastroenterologist } \\
\text { NS }\end{array}$ & 0 & 0 & 1 & 1,3 \\
\hline $\begin{array}{l}\text { Infectious disease doctor } \\
\text { NS }\end{array}$ & 0 & 0 & 0 & 0 \\
\hline $\begin{array}{l}\text { Gynaecologist } \\
\text { NS }\end{array}$ & 9 & 81,8 & 1 & 1,3 \\
\hline $\begin{array}{l}\text { Dentist } \\
\text { NS }\end{array}$ & 12 & 57,1 & 3 & 1,3 \\
\hline $\begin{array}{l}\text { Surgeon } \\
\text { NS }\end{array}$ & 1 & 5,6 & 2 & 1,3 \\
\hline $\begin{array}{l}\text { GP } \\
\text { NS }\end{array}$ & 2 & 10,0 & 1 & 2,5 \\
\hline $\begin{array}{l}\text { Internist } \\
\text { NS }\end{array}$ & 2 & 10,5 & 0 & 2,5 \\
\hline $\begin{array}{l}\text { Invasive cardiologist } \\
\text { NS }\end{array}$ & 0 & 0 & 0 & 0,0 \\
\hline $\begin{array}{l}\text { Angiologist } \\
\text { NS }\end{array}$ & 0 & 0 & 0 & 1,3 \\
\hline $\begin{array}{l}\text { Urologist } \\
\text { NS }\end{array}$ & 1 & 5,3 & 0 & 1,3 \\
\hline $\begin{array}{l}\text { Hematologist } \\
\text { NS }\end{array}$ & 0 & 0 & 0 & 0 \\
\hline $\begin{array}{l}\text { Otolaryngologist } \\
\text { NS }\end{array}$ & 0 & 0 & 0 & 0 \\
\hline $\begin{array}{l}\text { Orthopaedist } \\
\text { NS }\end{array}$ & 0 & 0 & 0 & 0 \\
\hline $\begin{array}{l}\text { Psychiatrist } \\
\text { NS }\end{array}$ & 1 & 5,6 & 0 & 0 \\
\hline $\begin{array}{l}\text { Doctor of other specialty } \\
\text { NS }\end{array}$ & 2 & 11,8 & 1 & 1,2 \\
\hline $\begin{array}{l}\text { Plastic surgeon } \\
\text { NS }\end{array}$ & 0 & 0 & 1 & 1,2 \\
\hline $\begin{array}{l}\text { Dermatologist and pulmonologist } \\
\text { NS }\end{array}$ & 1 & 1,2 & 0 & 0 \\
\hline $\begin{array}{l}\text { Doctor of unknown specialty who was at the hospital emergency ward } \\
\text { NS }\end{array}$ & 1 & 1,2 & 0 & 0 \\
\hline
\end{tabular}

NS - lack of statistical significance 
Table 6. Refusal to provide treatment by medical staff after the patient's information about the virus.

\begin{tabular}{|l|l|c|c|c|c|}
\hline \multirow{2}{*}{\multicolumn{2}{|c|}{}} & \multicolumn{3}{c|}{ Group } \\
\cline { 2 - 6 } \multicolumn{2}{|c|}{ Medical staff refusing to provide medical service } & \multicolumn{2}{|c|}{ HIV } & \multicolumn{2}{c|}{ HCV } \\
\cline { 2 - 6 } & Number & [\%] & Number & {$[\%]$} \\
\hline $\begin{array}{l}\text { Nurse } \\
\text { NS }\end{array}$ & Yes & 4 & 20,0 & 0 & 0 \\
\hline $\begin{array}{l}\text { Midwife } \\
\text { NS }\end{array}$ & Yes & 1 & 12,5 & 0 & 0 \\
\hline $\begin{array}{l}\text { Dental technician } \\
\text { NS }\end{array}$ & Tes & 2 & 9,5 & 0 & 0 \\
\hline $\begin{array}{l}\text { Laboratory diagnostician } \\
\text { NS }\end{array}$ & Yes & 0 & 0 & 0 & 0 \\
\hline $\begin{array}{l}\text { Registrar } \\
\text { NS }\end{array}$ & Yes & 0 & 0 & 0 & 0 \\
\hline $\begin{array}{l}\text { Another member of medical staff } \\
\text { NS }\end{array}$ & Yes & 0 & 0 & 0 & 0 \\
\hline
\end{tabular}

NS - lack of statistical significance

160 patients were included in the study - both women and men -80 patients with HIV/AIDS and 80 patients with HCV. The mean age of patients with HIV was 38.2 years, and of patients with HCV 50.9 years. The surveyed patients were mainly residents of Małopolska (81.3\%), Podkarpacie (8.8\%) and Masovia (5\%), the Świętokrzyskie Voivodeship (3.8\%) and Silesia $(1.3 \%)$. The research was carried out at the two clinics of the University Hospital in Krakow at 16 Śniadeckich Street, that is, the Clinic of Acquired Immunodeficiency and the Clinic of Viral Hepatitis functioning within the Clinical Department of Gastroenterology and Hepatology and Infectious Diseases of the University Hospital based on an original questionnaire - the same for the basic group (HIV / AIDS) as well as for the control group (HCV). The research was carried out in a parallel manner in these two groups of respondents so that a comparison could be made as to whether discrimination and stigmatization occurred in both groups (Tab. 1-7) [32].

\section{RESULTS}

The results of the study showed that some patients refused to visit a general practitioner or a specialist $(25 \%$ of patients with HIV and $2.5 \%$ of patients with $\mathrm{HCV}$ ), despite the fact that their symptoms had worsened or increased (both related and non-related to $\mathrm{HCV} / \mathrm{HIV}$ infection) or despite noticeable deterioration of health. Among the most common reasons for resigning from a visit to the clinic to obtain medical advice were: bad treatment in the past by medical personnel in the clinic or office because of HIV infection (13.9\%) and fear of a reaction of a physician (13.8\%) or other medical staff member to a message about the infection (13.8\%). The surveyed HIV patients also pointed to the bad treatment in the past in a private medical office by medical personnel $(12.5 \%)$, resignation from visiting the clinic due to earlier instilling in them a sense of guilt by the medical staff $(10 \%)$ as well as the resignation from a visit to the clinic due to their ill treatment by medical staff in the hospital ward (7.5\%). In total, $8.8 \%$ of patients gave up their appointments in the past due to a collision of hours of the work of the outpatient clinic/clinic with their professional $(6.3 \%)$ or family duties or other reasons $(3.8 \%)$. The same reasons for resignation from obtaining health services were indicated by patients with $\mathrm{HCV}$, but the percentage distribution of responses ranged between 1.3 and 2.5\% of respondents at each of the response options.

The patients were also asked if they had experienced a refusal to obtain medical care because of HIV or HCV infection. The results of the study showed that $27.5 \%$ of HIV patients and $7.5 \%$ of HCV patients met with refusal after providing information about infection. Patients with HIV experienced a refusal to have a dental consultation $(54.5 \%)$ or a medical consultation (38.4\%), whereas patients with HCV were refused only a dental consultation (50\%). Both patients with HIV and HCV experienced refusal of dental surgery (HIV 59.1\%, HCV 50\%), gynecological examination (HIV 38.9\%, HCV 40\%), a medical procedure under local anesthesia (HIV 15\%, HCV 16.7\%), or surgery 
Table 7. Behaviour of medical staff during the refusal of providing medical service.

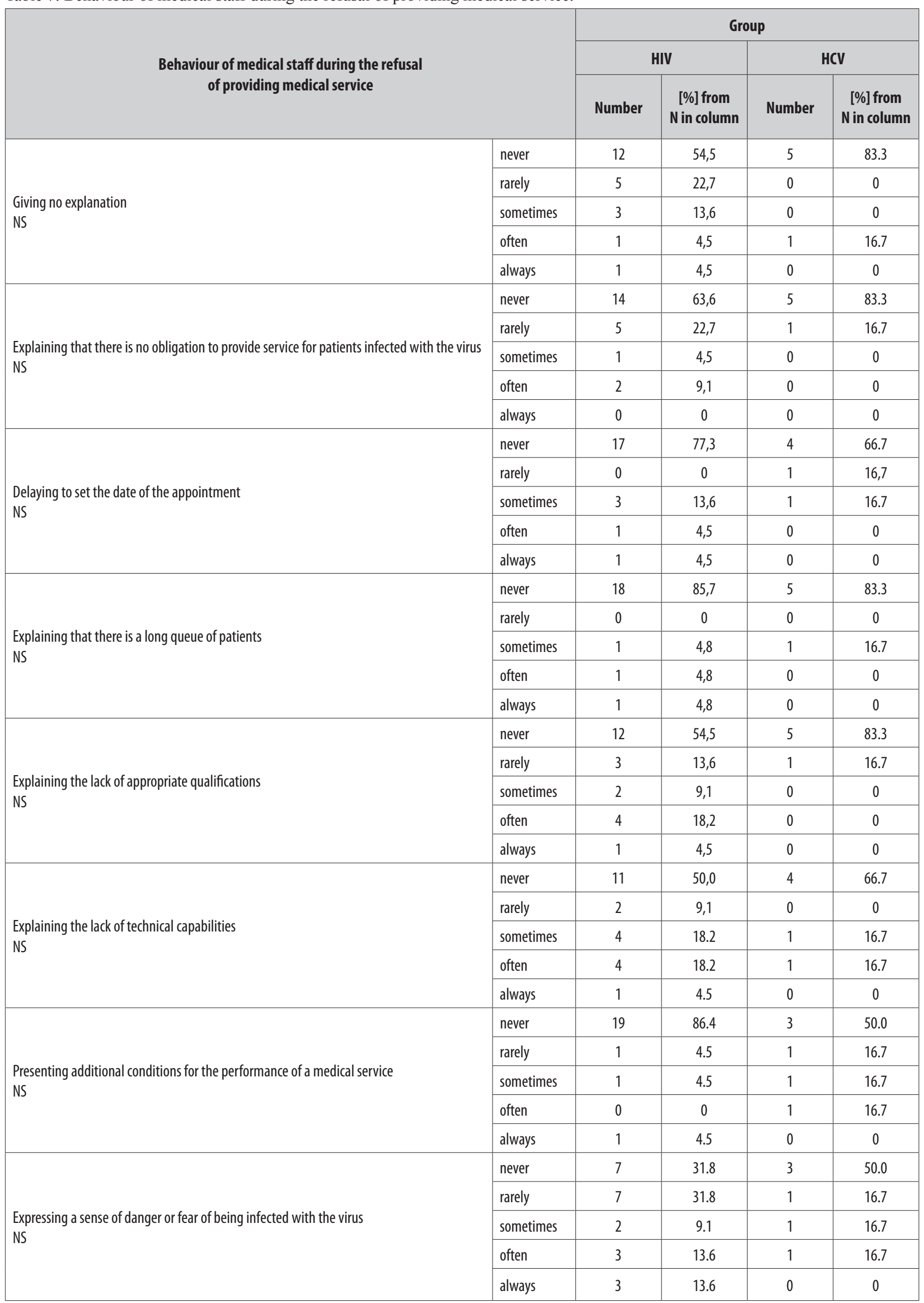




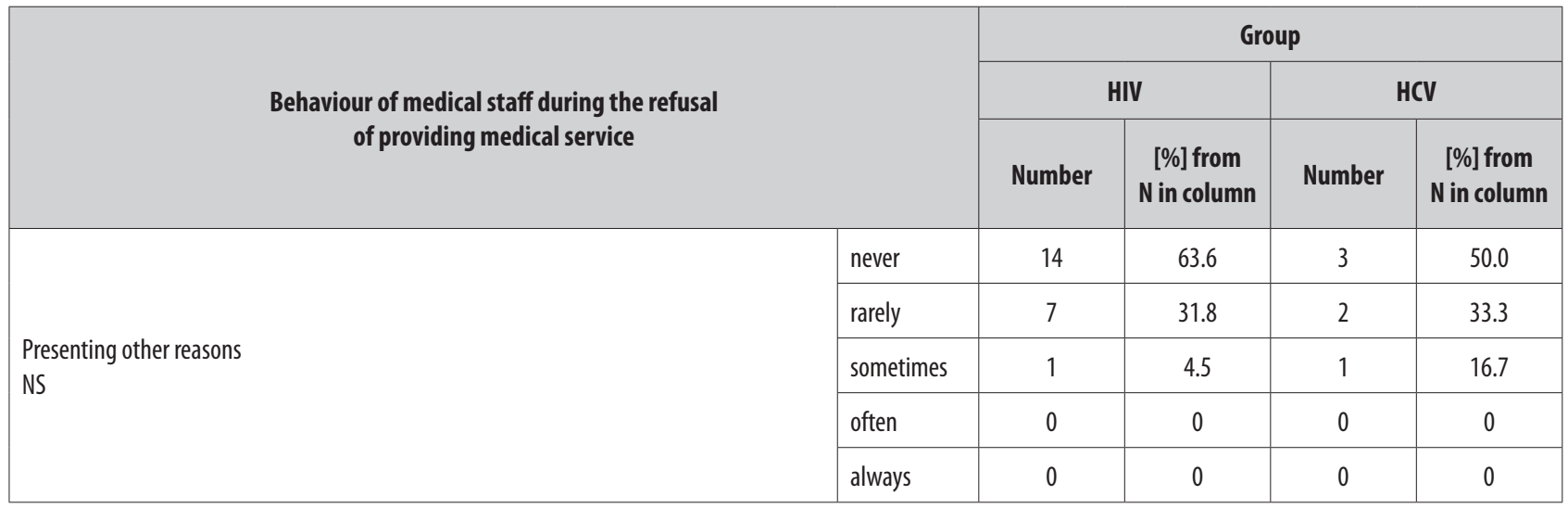

NS - lack of statistical significance

under general anesthesia (11.8\% HIV, 16.7\% HCV). In addition to indicating the situation in which the health services were refused, the patients were also asked to indicate which representatives of medical professions refused to provide them with medical care after finding out that they had a diagnosed HIV or HCV infection. The studies have shown that the most often they were refused by gynecologists, which was experienced by $81 \%$ of female patients with HIV and $33.3 \%$ of patients with HCV. The second group were dentists $-57.1 \%$ of patients with $\mathrm{HIV}$ and $50 \%$ of patients with $\mathrm{HCV}$ stated that they were refused dental care. Among other medical specialties, there were surgeons who refused to provide surgical assistance for 5.6\% HIV patients and $33.3 \%$ of $\mathrm{HCV}$ patients, doctors from out-patient clinics refused $10 \%$ of HIV patients and $16.7 \%$ of $\mathrm{HCV}$ patients as well as internists, psychiatrists and urologists who refused treatment only for HIV patients in $10.5 \%$, $5.6 \%$, and $5.3 \%$ of cases, respectively. The situation of refusal to provide health services was also met by HIV patients on the part of nurses (12.5\%), midwives $(20 \%)$, dental technicians $(9,5 \%)$ whereas there were no cases of such refusal among HCV patients.

According to the patients from the study group, they did not meet any form of stigmatization and discrimination by paramedics, despite an increased risk of their direct exposition to potentially infectious material during their interventions in life-threatening health conditions. One of the patients (50 years old) with HIV reported a case of stigmatization and discrimination in one of the emergency hospital wards in Kraków. According to the patient, a physician working there, refused to provide health services for him saying: "There is no place for you here". After having a look at the patient's information card, he pointed to the information about HIV infection, and ordered to leave the room. The patient complained of severe abdominal pain, and medical help was delivered in another place.
Almost half of patients with HIV (45.5\%) and a dozen or so patients with HCV $(16.7 \%)$ stated that when refusing to provide health service, the medical staff did not give any explanation. The patients were also asked whether the medical staff explained refusing to provide medical care by the lack of obligation to provide the service for infected persons $-36.4 \%$ of patients with HIV and $16.7 \%$ of patients with $\mathrm{HCV}$ admitted that such situations occurred. The excuses for refusing to provide patients with medical care given by medical staff were too long queues of patients (indicated by $14.3 \%$ of HIV patients and $16.7 \%$ of HCV patients), the lack of appropriate qualifications $(45.5 \%$ of HIV patients and $16.7 \%$ of $\mathrm{HCV}$ patients), and the lack of technical capabilities (50\% of HIV patients and 33.3\% of HCV patients). The patients were also asked whether in situations when they were refused the services, they were offered other conditions for the performance of the service - this was reported by $13.6 \%$ of HIV patients and $50 \%$ of HCV patients. The patients were also asked whether in the situation of refusal to provide services, medical personnel expressed threat or fear of infection with HIV or HCV - this was indicated by $68.2 \%$ of HIV patients and $50 \%$ of $\mathrm{HCV}$ patients [32].

\section{DISCUSSION}

Stigmatization and discrimination of patients especially with HIV is, on the one hand, a problem for patients due to the fact that its practical manifestations are worse treatment or refusal to provide services, on the other hand, it is a challenge for medical personnel, because such situations are associated with a negative perception of the disease and feeling of danger and fear of infection. This problem may arise from insufficient knowledge about the ways of transmission of bloodborne viruses. A great advance in medicine has been made since the detection of both viruses in the field of diagnostics and treatment of these viruses, and the 
knowledge about the risk of infection with these types of viruses has become publicly available. However, still among the representatives of medical professions in Poland - doctors, dentists, nurses and midwives are situations having a negative impact on the treatment process of these patients caused by negative attitudes towards them, resulting solely from the fact that they have the virus [33-39].

Research carried out till now, both in Poland, some other European countries and in various parts of the world, show that cases of discrimination and stigmatization on the part of medical staff, constitute a significant problem for infected patients manifested by posing obstacles or even preventing access to necessary medical care [40-55].

Research into the problem of stigmatization and discrimination against patients by medical personnel that has been performed hitherto in Poland has become the source of basic and important knowledge about the nature of stigma and discrimination mainly related to, among others, ill or unethical treatment, non-admission to the hospital, refusal to perform the procedure, or provide consultations at the clinic or at the doctor's or dentist's office. This knowledge should be constantly updated and include studies of both manifestations and reasons for stigmatization and discrimination as well as analyses comparing these patients with other groups of patients [33-39, 55-60].

When looking for a correlation between the results quoted above and own research, it should be pointed out that the types of behaviors and attitudes of the medical staff towards HIV patients are very similar, manifested by worse treatment due to the very fact of having infection, impediments in access to health services or refusal to provide medical care. The results of the research presented in this article as well as other Polish studies cited here confirm two other relationships important from the point of view of the diagnosis and treatment: some patients do not report their infection because they are afraid of the reaction of the staff, or the infected patients abandon medical care, despite existing health needs because of previously experiencing negative attitudes of medical personnel towards them. Another significant problem raised both in the authors' and other researchers' analyses is that some of the medical staff express fear or threat of HIV infection, and some do not possess - in the view of patients - appropriate qualifications or knowledge about routes of blood-borne viral infections, which is indispensable for providing adequate medical care for an infected patient.

It is worth mentioning that both the previous research conducted in Poland and the results of the authors' own research haven't revealed any cases of stigmatization and discrimination against patients by paramedics because of their patients' serological status. This information seems to be important taking into account the fact that, among medical professions, mainly paramedics, during their medical emergency treatment, are directly exposed to biological material and, in result, to blood-borne infections [61]. Additionally, refusal of medical services by paramedics during interventions in life-threatening health conditions - in case of obtaining information from patient about acquired HIV or HCV - would be associated with more serious and irreparable consequences for patients, than the refusal or postponing the term of a planned medical or dental consultation.

It does mean that the problem of stigmatization and discrimination does not exist in the system of the state Medical Emergency Services (MES), which was shown by an incident of refusal to provide medical services to the patient with HIV by one of the physicians in the hospital emergency ward in Krakow, which proves that the problem requires further monitoring among all medical professions.

\section{CONCLUSIONS}

1. The cases of stigmatization and discrimination against patients on the part of medical personnel occur when the medical staff learns that the patient is infected with HIV or HCV. The main manifestations of this phenomenon are impediments or preventing access to health services.

2. According to the patients, the sources of reactions and attitudes of medical staff are a sense of fear or a threat of infection, which can be related to the insufficient level of knowledge about virus transmission, while one of the reasons for refusing the care, given by the patients, was "the lack of appropriate qualifications". The effects of earlier negative experiences of the patients with medical personnel is that some patients resign from a visit to a general practitioner or a specialist despite occurrence of symptoms or noticeable exacerbation of their condition - both related and unrelated to HIV or HCV.

3. Resignation of patients from medical care despite the need for it due to previous negative experience in this area as well as difficulties in access to medical care or refusal of services may have negative health consequences. In the longer term, this situation can generate higher costs for the health care system due to the abandonment of earlier health-oriented activities of a diagnostic or therapeutic nature. 


\section{REFERENCES}

1. Wojciechowska J. Przyczyny dyskryminacji osób żyjących z HIV: nowe ujęcie teoretyczne i jego implikacje dla edukacji zdrowotnej. Gdańsk: Wydawnictwo Uniwersytetu Gdańskiego, 2011, pp. 91-121, 152-208.

2. Scambler G. Sociology, social structure and health-related stigma psychology. Health Med 2006;11(3):288-95.

3. Scambler G. Health-related stigma. Sociol Health Illness 2009;31(3):441-55.

4. Scambler G. Re-framing Stigma: Felt and enacted stigma and challenges to the sociology of chronic and disabling conditions. Social Theory Health 2004;2(1):29-46.

5. Scambler G., Paoli F.: Health work, female sex workers and HIV/AIDS: Global and local dimensions of stigma and deviance as barriers to effective interventions. Social Sci Med 2008;66:1848-62.

6. Gray JA. Stigma in psychiatry. J R Soc Med 2002;95(2):72-76.

7. Wojciechowska J. Stygmat i dyskryminacja jako trzecia faza epidemii HIV/AIDS. Gdańsk: Wydawnictwo Uniwersytetu Gdańskiego, 2004; pp. 57-81, 93-121, 122-55.

8. Winiarska A, Klaus W. Dyskryminacja i nierówne traktowanie jako zjawisko społeczno-kulturowe. Studia BAS, Warszawa 2011;2(26):9-40.

9. Łotocki Ł. Integracja i dyskryminacja - krajobraz 2009. Warszawa: Instytut Spraw Publicznych, 2009, pp. 11-27. Accessed November 15 2017. Available at http://www.isp.org.pl/files/ 15092712760608654001258628195.pdf.

10. Kudlińska I. Stygmatyzacja społeczna jako perspektywa teoretyczno-badawcza (na przykładzie badań nad stygmatyzacją ludzi biednych). Acta Univ Lodz, Folia Sociol, Łódź 2011;38:51-72.

11. Kenrick TD, Neuberg SL, Cialdini RB. Psychologia społeczna. Gdańsk: Gdańskie Wydawnictwo Psychologiczne, 2002, pp. 544-83.

12. Crocker J, Quinn DM. Piętno społeczne i Ja: znaczenia, sytuacje i samoocena. In: Heatherton TF, Kleck RE, Hebl MR, Hull JG (eds). Społeczna psychologia piętna. Warszawa: Wydawnictwo Naukowe PWN, 2008, pp. 147-204.

13. Herek GM, Capitanio JP. Widaman KF. HIVRelated stigma and knowledge in the United States: prevalence and trends, 1991-1999. Am J Public Health 2002;92(3):71-7.

14. Sztompka P. Socjologia. Analiza społeczeństwa. Kraków: Wydawnictwo Znak, 2002, pp. 288-307.
15. Winiarska A, Klaus W. Dyskryminacja i nierówne traktowanie jako zjawisko społeczno-kulturowe. Studia BAS, Warszawa 2011;2(26):9-40.

16. Wojciechowska J. Przyczyny dyskryminacji osób żyjących z HIV: nowe ujęcie teoretyczne i jego implikacje dla edukacji zdrowotnej. Gdańsk: Wydawnictwo Uniwersytetu Gdańskiego, 2011, pp. 91-121, 152-208.

17. Lisiak T. Wykluczenie społeczne oraz grupy zagrożone marginalizacją. Accessed May 152014. Available at http://www.ie-ries.com.pl/archiwum/ artykuly/RIES_20100625948_wykluczenie_ spoleczne.pdf.

18. WHO. Global health sector strategy on HIV/ AIDS 2011-2015. Accessed May 52014. Available at http://whqlibdoc.who.int/ publications/2011/9789241501651_eng.pdf?ua=1.

19. Decision No $1098 / 2008 / \mathrm{EC}$ of the European Parliamentand of the Council.Official JEuropUnion 2008 Nov 11. Accessed May 15 2014. Available at http://eur-lex.europa.eu/LexUriServ/LexUriServ. do?uri=OJ:L:2008:298:0020:0029:EN:PDF.

20. MPiPS: Rok 2010 - Europejskim Rokiem Walki z Ubóstwem i Wykluczeniem Społecznym. Accessed May 15 2014. Available at http:// www.mpips.gov.pl/pomoc-spoleczna/rok-20108211-europejskim-rokiem-walki-z-ubostwem-iwykluczeniem-spolecznym/.

21. Gottlieb MS, Schanker HM, Fan PT, Saxon A, Weisman JD, Pozalski I. Pneumocystis Pneumonia - Los Angeles. MMWR 1981;30(21):250-52.

22. Gottlieb MS, Schroff R., Schanker HM, et al. Pneumocystis carinii pneumonia and mucosal candidiasis in previously healthy homosexual men. NEJM 1981;305(24):1425-31

23. Centers for Disease Control. Current trends update on Acquired Immune Deficiency Syndrome (AIDS) - United States. MMWR 1982;31(37):5078, 513-4.

24. Gallo RC, Haynes BF, Kaplan M, et al. Frequent detection and isolation of cytopathic retroviruses (HTLV-III) from patients with AIDS and at risk for AIDS. Science 1984;224(4648):500-3.

25. Ratner L, Gallo RC, Wong-Staal F. HTLV-III, LAV, ARV are variants of same AIDS virus. Nature 1985;313:636-7.

26. Coffin J, Haase A, Levy JA, et al. What to call the AIDS virus? Nature 1986;321(6065):10.

27. Rogala M. Grupy ryzyka zarażeniem HIV w latach 1981-1986. Zesz Nauk Ochrony Zdr Zdr Publ Zarz 2012;10(A):72-9.

28. Gallo RC. A reflection on HIV/AIDS research after 25 years. Retrovirology 2006;3:72. 
29. Cohen J. Haiti - making headway under hellacious circumstances. Science 2006; 313(5786):470-3.

30. Ostrowska A. Oswajanie HIV w Polsce. Accessed Aug 10 2014. Available at http://www. pozytywnieotwarci.pl/artykuly.html.

31. Wysocki M, Gierczyński J, Gibska-Kuczerowska A (eds). Aspekty systemowe i ekonomiczne WZW typu C w Polsce z perspektywy zdrowia publicznego. Warszawa: Narodowy Instytut Zdrowia Publicznego - Państwowy Zakład Higieny, 2017.

32. Rogala M. Samoocena przypadków stygmatyzacji i dyskryminacji ze strony personelu medycznego pacjentów z rozpoznanym HIV i z AIDS (praca doktorska), UJ CM, Kraków, 2015.

33. Ankiersztejn-Bartczak M. 25 lat HIV w Polsce. Czy coś się zmieniło? Fam Med Prim Care Rev 2012;14(1):71-75.

34. Hauza T. Społeczeństwo wobec „innego" stygmat i dyskryminacja a kwestia HIV/AIDS. Scripta Comeniana Lesnensia, PWSZ im. J. A. Komeńskiego w Lesznie 2010;8:69-85.

35. Bażydło M, Karakiewicz A, Kotwas A, Zabielska $\mathrm{P}$, Rotter I. Stigmatisation and social discrimination against HIV-infected persons in the light of relevant literature. J Publ Health, Nurs Med Resc 2014;3:18-24.

36. Jabłonowska E, Małolepsza E. Stopień akceptacji pacjentów HIV+ przez pracowników służby zdrowia w regionie łódzkim $\mathrm{w}$ ocenie samych zakażonych. Wiad Lek 2007;60:11-2.

37. Rogowska-Szadkowska D, Pentkowska E, Chlabicz S. Wiedza ginekologów i położnych na temat ryzyka transmisji wertykalnej HIV. Ginekol Pol. 2008;79: 862-6.

38. Ankiersztejn-Bartczak M. Jakość życia osób żyjących z HIV/AIDS - cz. I., Remedium 2008;3(181):23-4

39. Gańczak M, Szych Z. Surgeons and their concerns of acquiring HIV infection. Ortop Traumatol Rehab 2004;6(1):134.

40. Abadia-Barrero CE, Castro A. Experiences of stigma and access to HAART in children and adolescents living with HIV/AIDS in Brazil. Soc Sci Med. 2006;62(5):1219-28.

41. Biswas HA. AIDS epidemic worldwide and the millennium development strategies: A light for lives. HIV AIDS Rev 2012;11(4):87-94.

42. Brown L, Macintyre K, Trujillo L. Interventions to reduce HIV/AIDS stigma: What have we learned? AIDS Educ Prevent 2003;15:49-69.

43. Dunn LB, Green Hammond KA, Roberts LW. Delaying care, avoiding stigma: residents' attitudes toward obtaining personal health care. Acad Med 2009;84(2):242-50.

44. Foreman M, Lyra P, Breinbauer C. Understanding and responding to HIV/AIDS related stigma and discrimination in the health sector. Washington DC: Pan American Health Organization 2003.

45. Horstmann E, Brown J, Islam F, Buck J, Agins BD. Retaining HIV-infected patients in care: Where are we? Where do we go from here? Clin Infect Dis 2010; 50(5):752-61.

46. Li L, Wu Z, Wu S, Zhaoc Y, Jia M, Yan Z. HIVrelated stigma in health care settings: a survey of service providers in China. AIDS Patient Care STDS 2007;21(10):753-62.

47. Mahendra VS, Gilborn L, Bharat S, et al. Understanding and measuring AIDS-related stigma in health care settings; a developing country perspective. SAHARA J 2007;4(2):616-25.

48. Mahendra VS, Gilborn L, George B, et al. Reducing AIDS-related stigma and discrimination in Indian hospitals. Horizons Final Report. New Delhi, Population Council 2006.

49. Nyblade L, Hong KT, Van Anh N, et al. Communities confront HIV stigma in Viet Nam: participatory interventions reduce HIV-related stigma in two provinces. Washington, D.C. and Hanoi, International Center for Research on Women (ICRW), Institute for Social Development Studies 2008.

50. Sadoh AE, Fawole AO, Sadoh WE, Oladimeji AO, Sotiloye OS. Attitude of health-care workers to HIV/AIDS. Afr J Reprod Health 2006;10(1):39-46.

51. Stein JA, Li L. Measuring HIV-related stigma among Chinese service providers: confirmatory factor analysis of a multidimensional scale. AIDS Behav 2008;12(5):789-95.

52. Ware N, WyattM, Tugenberg T. Social relationships, stigma and adherence to antiretroviral therapy for HIV/AIDS. AIDS Care 2006;18(8):904-10.

53. Sadoh AE, Sadoh WE, Fawole AO, Oladimeji A, Sotiloye O. Attitude of health care workers to patients and colleagues infected with human immunodeficiency virus. SAHARA J 2009;6(1):17-23.

54. Zukoski AP, Thorburn S. Experiences of stigma and discrimination among adults living with HIV in a low HIV-prevalence context: a qualitative analysis. AIDS Patient Care \& STDs 2009;23:267-76.

55. GNP+, HIV in Europe, Ogólnopolska Sieć Osób Żyjących z HIV/AIDS „Sieć Plus”: Ludzie żyjący z HIV Stigma Index. Warszawa: Sieć Plus, 2011. Accessed Sep 5 2014. Available at http://leczhiv. p1/stigmaindex.pdf. 
56. Rogowska-Szadkowska D, Ołtarzewska AM, Sawicka-Powierza J, Chlabicz S. Medical care of HIV-infected individuals in Poland: impact of stigmatization by health care workers. AIDS Patient Care STDS 2008;22(1):81-4.

57. Ankiersztejn-Bartczak M. Psychospołeczna sytuacja osób żyjących z HIV i chorych na AIDS w Polsce (praca doktorska). Warszawa 2103. Accessed Sep 5 2014. Available athttps://depotuw. ceon.pl/bitstream/handle/item/422/praca $\% 20 \% 20$ $\mathrm{dr} \% 20 \mathrm{MAB} \% 20 \mathrm{OST}$.pdf? sequence $=1$.

58. Lickiewicz B, Bociąga-Jasik M, Lickiewicz J, Loster J, Garlicki A, Mach T. Pacjenci nie informują lekarzy stomatologów o zakażeniu wirusem HIV - obserwacje własne. Mag Stomatol 2013;23(11):125-9.

59. Rogowska-Szadkowska D, Chlabicz S, Gąsiorowski J, Zubkiewicz-Zarębska A, Knysz B. Experience of Polish patients diagnosed with HIV before and after highly active antiretroviral therapy (HAART) availability. HIV AIDS Rev 2013;12(1):9-13.

60. Gańczak M.: Stigma and discrimination for HIV/ AIDS in the health sector: a Polish perspective. Interam J Psychol 2007;41(1):57-66.

61. Gańczak M, Topczewska K. Risk of occupational exposure to blood-borne pathogens in paramedics. Med Prac 2018;69(6):685-694.

\section{ORCID:}

Maciej Rogala - 0000-0001-8104-7617

Ewa Donesch-Jeżo - 0000-0002-4655-8822

\section{Conflict of interest:}

The Authors declare no conflict of interest.

\section{Address for correspondence:}

Maciej Rogala

Zakład Polityki Zdrowotnej i Zarządzania, Instytut Zdrowia Publicznego,

Wydział Nauk o Zdrowiu, Uniwersytet Jagielloński Collegium Medicum ul. Grzegórzecka 20, Kraków e-mail: maciej.rogala@uj.edu.pl

Received: 15.07.2019

Accepted: 10.09.2019 